\author{
JURNAL PENELITIAN BAHASA, SASTRA, DAN \\ BUDAYA ARAB \\ P-ISSN: 2615-7241 | E-ISSN: 2721-480X // Vol. 1 No. 1 | 73-87 \\ (1) https://ejournal.upi.edu/index.php/alsuniyat/index
}

\title{
SUDAHKAH EVALUASI KEMAHIRAN BERBICARA BAHASA ARAB PADA TINGKAT DASAR DILAKUKAN?
}

\author{
Laili Nur Kholisoh \\ Universitas Negeri Jakarta, Indonesia \\ Email: lailynurkholisoh@gmail.com
}

\begin{abstract}
:
Evaluation is something that is commonplace and even just flows in accordance with the calendar of education. This research aims to find out and look for a solution of the problems that occur when implementing an evaluation for Arabic speaking skills at the level of data done by observation and interviews to several Arabic language teachers at the elementary level. With the data already obtained the writer to study literature to relate some of the problems with the existing theories to find relevant solutions for each issue found. As for some of the problems found related to the evaluation of speaking skills of students at the primary level, including the following: 1) Teachers often neglect the evaluation of speaking skills for being too focused on the written evaluation, 2) time is inadequate also make teachers second priority to this evaluation, 3) Teachers admitted the difficulty to make the right instrument for the evaluation of speaking skills, and 4) the ability of students limited hamper the ongoing evaluation of speaking skills. From some of the existing problems, there are several solutions to overcome them. One was a teacher must adjust the evaluation of speaking skills are as important as some other language proficiency evaluation.
\end{abstract}

Keywords:

Evaluation; Communication skills; Arabic

\begin{abstract}
Abstrak:
Evaluasi sebenarnya merupakan sesuatu yang lumrah dan bahkan mengalir begitu saja sesuai dengan kalender pendidikan. Penulisan ini bertujuan untuk mengetahui serta mencari solusi tentang problematika yang terjadi saat melaksanakan evaluasi untuk kemahiran berbicara bahasa Arab pada tingkat dasarPengumpulan data dilakukan dengan observasi dan wawancara kepada beberapa pengajar bahasa Arab di tingkat dasar. Dengan data-data yang sudah didapat penulis melakukan studi pustaka untuk mengkaitkan beberapa masalah dengan teori-teori yang ada untuk menemukan solusi yang relevan bagi setiap maslah yang ditemukan. Adapun beberapa masalah yang ditemukan terkait pelaksanaan evaluasi kemahiran berbicara siswa di tingkat dasar, diantaranya sebagai berikut: 1) Guru sering mengabaikan evaluasi untuk keterampilan berbicara karena terlalu fokus pada evaluasi tertulis, 2) Waktu yang kurang memadai juga membuat guru menomor duakan evaluasi ini, 3) Pengajar mengaku kesulitan untuk membuat instrumen yang tepat untuk evaluasi kemahiran berbicara, dan 4) Kemampuan siswa yang terbatas menghambat berlangsungnya evaluasi kemahiran berbicara. Dari beberapa permasalahan yang ada, terdapat beberapa solusi untuk mengatasinya. Salah satunya adalah guru harus menepatkan evaluasi kemahiran berbicara sama pentingnya dengan beberapa evaluasi kemahiran berbahasa lainnya.

Kata Kunci:

Evaluasi; Keterampilan berbicara; Bahasa Arab
\end{abstract}

\section{PENDAHULUAN}

Pembelajaran bahasa Arab merupakan proses pembelajaran peserta didik agar mereka mampu menguasai empat keterampilan berbahasa. Keterampilan dalam bahasa Arab adalah Al-Maharah, secara bahasa al-maharah memiliki arti mempuni atau dalam arti 
berdiri sendiri dalam setiap sesuatu perkerjaan, sebagaimana diungkapkan Mandzur (2011):

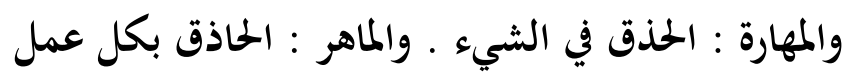

Empat keterampilan berbahasa yang dimaksud diatas diantaranya: menyimak, berbicara, membaca, dan menulis. Keterampilan berbicara di dalam bahasa Arab disebut juga dengan maharatul kalam yang merupakan keterampilan kedua yang harus dikuasai oleh pembelajar bahasa setelah keterampilan menyimak. Berbicara merupakan sarana utama untuk membina komunikasi timbal balik, dengan menggunakan bahasa sebagai medianya. Kegiatan berbicara di dalam kelas bahasa mempunyai aspek komunikasi dua arah, yakni antara pembicara dengan pendengarnya secara timbal balik. Dengan demikian latihan berbicara harus terlebih dahulu didasari oleh kemampuan mendengarkan, kemampuan mengucapkan, dan penguasaan kosa kata serta ungkapan yang memungkinkan anak didik dapat mengkomunikasikan maksud atau fikirannya. Menurut Effendy (2005:112) berbicara merupakan sarana utama untuk menyampaikan pesan melalui bahasa lisan kepada orang lain. Berbicara identik dengan penggunaan bahasa secara lisan.

Sunendar dan Iskandarwassid (2008:241) mengungkapkan bahwa keterampilan berbicara pada hakikatnya merupakan keterampilan memproduksi arus sistem bunyi artikulasi yang bertujuan untuk menyampaikan kehendak, kebutuhan perasaan, dan keinginan kepada orang lain. Senada dengan yang diungkapkan oleh Sunendar dan Iskandarwassid, Hermawan (2011:135) juga berpendapat bahwa keterampilan berbicara (maharah al-kalam) adalah kemampuan mengucapkan bunyi-bunyi artikulasi atau katakata untuk mengekspresikan pikiran berupa ide, pendapat, keinginan, atau perasaan kepada mitra bicara.

Berkenaan dengan beberapa pendapat sebelumnya maka dalam pengajaran suatu bahasa keterampilan berbicara merupakan salah satu keterampilan yang harus dikuasai oleh pembelajar bahasa asing setelah keterampilan mendengar. Kemahiran berbicara merupakan salah satu jenis kemampuan berbahasa yang ingin dicapai dalam pembelajaran bahasa modern, termasuk bahasa Arab.

Dalam pembelajarannya maharatul kalam diaplikasikan dengan beberapa bentuk seperti dengan percakapan, mengungkapkan suatu ide atau gagasan yang singkat, dan lain 
sebagainya. Dimana kegiatan-kegiatan tersebut dapat membantu tercapainya tujuan pembelajaran maharah kalam itu sendiri. Dalam proses pembelajaran untuk mengetahui hasil akhir dari proses tersebut perlu diadakannya tahap evaluasi.

Evaluasi hasil pembelajaran merupakan siklus rutin dari sebuah aktivitas pendidikan di berbagai tingkatan. Hampir mustahil suatu aktivitas pendidikan yang dituangkan dalam proses pembelajaran tidak dilaksanakan pula proses evaluasinya. Dengan demikian maka evaluasi sebenarnya merupakan sesuatu yang lumrah dan bahkan mengalir begitu saja sesuai dengan kalender pendidikan. Oleh karena dianggap sudah biasa, maka kerapkali prosesnya dilakukan dengan tidak semestinya, tanpa perencanaan yang matang, dan tanpa kiat-kiat strategis, tidak terarah, dan sebagainya. Dan begitu pula yang terjadi dalam pembelajaran bahasa Arab. Tidak dapat dipungkiri masih banyak sekali problematika yang terjadi dalam melaksanakan evaluasi untuk pembelajaran bahasa Arab, dimana pengajar dituntut untuk memperhatikan setiap kemahiran berbahasa siswanya. Untuk keterampilan berbicara sebagai kemahiran yang kedua dari ke lima ketrampilan lainnya, dalam pelaksanaan evaluasi kemahiran berbahasa,masih sering terabaikan.

Berdasarkan Peraturan Pemerintah No. 19 tahun 2005 tentang Standar Nasional Pendidikan, evaluasi hasil belajar dilakukan dengan penilaian hasil belajar yang bertujuan untuk memantau proses, kemajuan dan perbaikan hasil belajar serta untuk menilai pencapaian kompetensi peserta didik, sebagai bahan penyusunan laporan kemajuan hasil belajar dan untuk memperbaiki proses pembelajaran. Pada dasarnya, evaluasi dimaksudkan untuk memperoleh data atau informasi tentang jarak antara situasi yang ada dan situasi yang diharapkan dengan menggunakan kriteria-kriteria tertentu. Dengan menggunakan data dan informasi yang ada, guru dapat mengambil keputusan tentang kegiatan belajar mengajar selanjutnya. Agar proses evaluasi dapat berlangsung, maka instrumen evaluasi harus direncanakan, disusun, dan dilaksanakan. Salah satu instrumen evaluasi yang digunakan secara luas dan dapat mengukur sejauh mana kemampuan peserta didik dalam belajar adalah tes.

Tes sebagai salah satu alat evaluasi hasil belajar mempunyai peranan yang penting dalam mengukur prestasi hasil belajar siswa. Tes dapat memonitor keberhasilan, baik pengajar maupun siswa dalam mencapai tujuannya. Bagi siswa, tes dapat digunakan untuk mengetahui seberapa besar kemampuan yang telah diperoleh. Sedangkan bagi pengajar, tes dapat digunakan untuk mengetahui keefektivan pendekatan, metode, teknik, serta fasilitas 
yang digunakan dalam proses pembelajaran. Hal tersebut diperkuat oleh Supriadi (2013:6) yang menyatakan bahwa tes dilakukan untuk keuntungan kedua belah pihak, yaitu pengajar dan siswa. Tujuan tes ialah untuk mengetahui seberapa besar kemampuan pengajar dalam menyampaikan materi kepada siswa dan bagi siswa dapat mengetahui seberapa banyak materi yang mampu mereka serap selama proses pembelajaran. Dari hasil tes, pengajar/penyusun silabus dapat mengubah/ memperbaiki silabus, metode, dan media.

Menurut Harris (1969:2-4) tes bahasa mempunyai enam tujuan yang berhubungan dan tidak saling mengecualikan, yaitu: (1) untuk menentukan kesiapan siswa menerima suatu program pelajaran,(2) untuk mengelompokkan atau menempatkan siswa pada kelas yang tepat, (3) untuk mengetahui kekuatan dan kelemahan khusus individu yang dites, (4) untuk mengukur bakat belajar, (5) untuk mengukur luas pencapaian tujuan belajar pada siswa, dan (6) untuk menilai keefektivan pelajaran.

Tes bahasa sangat penting dalam pembelajaran bahasa, begitu pula dalam pembelajaran bahasa Arab. Seperti yang kita ketahui bahwasannya dalam pembelajaran bahasa Arab terdapat 4 aspek kemahiran bahasa yang harus diperhatikan tingkat keberhasilannya. Maka dari itu, tahap evaluasi untuk masing-masing kemahiran sangatlah diperlukan.

Menurut hemat penulis, dalam pelaksanaannya instrumen yang digunakan para pengajar pada tahap evaluasi pembelajaran bahasa Arab belum dapat mengukur keempat kemahiran berbahasa yang ada, khususnya di tingkat dasar. Salah satu kemahiran yang sering terabaikan dalam tahap evalusi adalah kemahiran berbicara. Tidak dapat dipungkiri bahwa dalam pelaksanaan suatu kegiatan terdapat beberapa problem yang dapat menghambat berlangsungnya kegiatan tersebut. Begitu pula dalam melaksanakan evaluasi keterampilan berbahasa yang ada. Terabaikannya keterampilan berbicara dalam tahap evaluasi tentu saja tidak terlepas dari beberapa problematika yang ada.

Dalam kesempatan kali ini penulis akan memaparkan beberapa problematika yang ada pada tahap evaluasi keterampilan berbicara bahasa Arab di tingkat dasar. Adapun tujuan dari penulisan makalah ini adalah sebagai berikut :

1. Untuk mengetahui urgensi evaluasi kemahiran berbicara bahasa Arab di tingkat dasar.

2. Untuk mengetahui problematika yang ada pada tahap evaluasi keterampilan berbicara bahasa Arab di tingkat dasar yang terjadi di lapangan. 
3. Untuk menemukan solusi yang relevan mengenai problematika yang terjadi di lapangan.

Untuk memenuhi beberapa tujuan penulisan diatas, penulis akan memaparkan masalah apa saja yang terjadi sehingga keterampilan berbicara dapat terabaikan baik secara teoritis dan empiris serta mencari solusi untuk menanggulanginya.

\section{METODE}

Metode yang penulis gunakan dalam membuat makalah ini adalah dengan menggunakan metode pustaka dimana penulis menggunakan sejumlah literatur untuk mengumpulkan informasi, membahas dan menyimpulkan permasalahan-permasalahan berdasarkan teori yang relevan.

Selain dengan metode pustaka, penulis juga melakukan suatu penelitian sederhana, dimana penelitian tersebut menggunakan pendekatan kualitatif. Dari pendekatan kualitatif yang digunakan dalam penelitian ini, data dan informasi yang diperoleh selanjutnya diorganisir dan dianalisis guna mendapat gambaran (deskripsi) tentang objek penelitian. Cara pengolahan data dan informasi yang demikian itu, kemudian diistilahkan dengan metode deskriptif analitis.

Adapuan data yang digunakan penulis diperoleh dari hasil pengamatan, hasil wawancara, hasil pemotretan, analisis dokumen, catatan lapangan observasi yang dilakukan oleh penulis di lapangan. Penulis melakukan pengamatan di lapangan, dengan pengamatan tersebut penulis mendapatkan gambaran secara umum proses pembelajaran bahasa Arab yang terjadi di tingkat dasar.

Adapun melalui wawancara, penulis melakukan wawancara pada beberapa guru dan siswa di tingkat dasar. Pada saat wawancara kepada guru penulis sedikit banyak mendengarkan keluhan-keluhan guru mengenai proses pembelajaran bahasa Arab yang belum berjalan semestinya serta problematika yang dirasakan oleh guru dalam proses belajar mengajar, adapun saat wawancara bersama beberapa siswa penulis mendapatkan 45\% siswa yang menyatakan bahwa bahasa Arab itu sulit. Selanjutnya penulis melakukan anilisis dokumen yang ada dilapangan, sampai pada akhirnya penulis tertarik untuk melihat instrumen tes yang digunakan guru untuk mengukur kemampuan siswa dalam belajar bahasa Arab. Pada tahap tersebut penulis beranggapan bahwa suatu tes harus mencakup empat keterampilan bahasa yang ada, sampai pada akhirnya penulis menemukan suatu fenomena bahwa untuk mengukur keterampilan berbicara bahasa Arab siswa guru masih sering merasa kesulitan. Dengan adanya fenomena tersebut, penulis 
melakukan observasi, wawancara, serta analisis dokumen lebih lanjut mengenai fenomena tersebut.

Dari hasil pengamatan yang lebih mendalam maka penulis menemukan beberapa problematika yang dirasakan oleh para guru dalam melaksanakan evaluasi kemahiran berbicara bahasa Arab siswa pada tingkat dasar. Dimana penulis beranggapan problematika tersebut perlu untuk dikaji untuk menemukan solusi yang dapat meminimalisisr problematika yang ada.

\section{HASIL DAN PEMBAHASAN}

Sebelum membahas mengenai problematika apa saja yang ada dilapangan dalam melaksanakan proses evaluasi kemahiran berbicara bahasa Arab di tingkat dasar, penulis akan memaparkan terlebih dahulu tentang seberapa pentingnya pelaksanaan evaluasi kemahiran berbicara. Untuk mengetahui urgensi melaksanakan tes kemahiran berbicara tentu saja tidak dapat terlepas dari tujuan keterampilan berbicara itu sendiri. Tujuan utama berbicara adalah untuk berkomunikasi. Komunikasi merupakan pengiriman dan penerimaan pesan atau berita antara dua orang atau lebih sehingga pesan yang dimaksud dapat dipahami. Oleh karena itu, agar dapat menyampaikan pesan secara efektif, pembicara harus memahami apa yang akan disampaikan atau dikomunikasikan.

Tujuan diatas menjelaskan bahwa memiliki kemahiran berbicara yang baik sangatlah diperlukan. Dalam mempelajari bahasa, khususnya bahasa Arab tentu memiliki suatu tujuan yang salah satunya adala mampu berkomunikasi secara lisan dengan menggunakan bahasa Arab dengan baik dan benar. Dan dalam proses pembelajarannya, untuk mengetahui kemampuan yang dimiliki peserta didik tentulah dibutuhkan suatu tes yang dapat menjadi evaluasi bagi pengajar dan peserta didik.

Dari kedua penjelasan sebelumnya, maka dapat disimpulkan bahwa melakukan tes dan mengevaluasi kemahiran berbicara bahasa Arab yang dimiliki siswa itu penting. Setelah mengetahui bahwa pentingnya melakukan evaluasi kemahiran berbicara bagi perta didik, penulis akan memaparkan beberapa problematika yang terjadi dalam proses pembelajaran maharah kalam. Karena hal ini dapat menghambat proses evaluasi yang akan dilaksanakan selanjutnya.

Setelah mengetahui seberapa pentingnya evaluasi dalam proses pembelajaran pada umumnya dan pentingnya mengevaluasi kemampuan siswa dalam berbicara bahasa Arab khususnya. Berikut penulis paparkan beberapa problematika yang terjadi di lapangan 
dalam pembelajaran kemahiran berbicara bahasa Arab di tingkat dasar. Problematika ini tentu memiliki pengaruh dalam pelaksanaan evaluasi kemahiran berbahasa siswa. Penulis menemukan beberapa problematika pembelajaran kemahiran berbicara yang terjadi di lapangan, hal ini didapat penulis dari hasil wawancara kepada guru dan siswa tingkat dasar, maka dari itu penulis akan mengkelompokkannya menjadi 2 sudut pandang, 1) problematika pembelajaran kalam dari sudut pandang guru, dan 2) problematika pembelajaran kalam dari sudut pandang siswa. Adapun problematika yang ada diantaranya sebagai berikut:

\section{Problematika Pembelajaran Kalam dari sudut pandang guru}

Pada saat proses pembelajaran berlangsung, tidak dipungkiri bahwasannya guru disekolah tersebut sedikit banyak menghadapi berbagai masalah yang bervariasi baik masalah yang sudah ditemukan solusinya taupun maih dalam tahap pencarian solusi. Adapun masalah- masalah yang dirasakan oleh guru pada pembelajaran maharah kalam di sebagai berikut:

1. Materi ajar yang terlalu sulit untuk siswa

Guru merasa bahwasannya materi ajar yang disediakan oleh sekolah masih terlalu sulit untuk tingkat dasar yang baru mengenal bahasa Arab. Dalam hal ini, guru mengatasinya dengan membuat diktat yang dirasa sesuai dengan kemampuan anak didiknya.

2. Metode dan media yang kurang bervariatif

Walaupun guru tersebut membuat materi ajarnya sendiri, akan tetapi dalam penyampainya guru beranggapan bahwasannya metode dan media yang digunakan masih monoton atau kurang bervariatif sehingga membuat anak didiknya tidak antusias untuk berpartisipasi dalam proses pembelajaran yang sedang berlangsung. Adapun metode yang sering digunakan guru pada saat mengajar yaitu metode langsung dengan menggunakan media gambar.

Pada dasarnya guru tersebut menyadari bahwasannya banyak metode yang bervariatif dan menarik untuk diterapkan dalam pembelajarannya khususnya untuk pembelajaran kalam. Misalnya saja metode-metode yang berkaitan dengan pendekatan cooperative learning. Akan tetapi guru merasa tidak yakin untuk menerapkan metodemetode tersebut karena lemahnya pengetahuan guru mengenai hal tersebut dan guru tersebut juga mengakhawatirkan pribadi dari masing-masing anak didiknya karena 
beliau beranggapan bahwasnnya siswa sekolah dasar masih harus dibimbing dengan sangat hati-hati dan harus diperhatikan satu persatu, sedangkan, metode yang ada sekarang sedikit banyak menerapkan konsep gotong royong atau bekerja secara kelompok. Dan media yang sangat sering digunakan adalah media gambar, dimana siswa diminta untuk menyebutkan kosakata dari gambar yang ada serta menghubungkannya dengan kata petunjuk (اسم الإشارة) dan menginformasikannya kepada teman-teman yang lain kemudian diulangi kembali oleh siswa lainnya secara bersamaan.

3. Evaluasi yang sering terlupakan

Tahap evaluasi sangat diperlukan bagi guru untuk mengetahui tingkat kemampuan yang telah dicapai peserta didik. Dalam pembelajaran bahasa Arab disekolah ini jenis evaluasi yang digunakan biasanya berupa tes secara tertulis, sehigga guru menyadari bahwasannya untuk mengukur kemampuan siswa dalam maharah kalam sering terabaikan karena untuk maharah kalam itu sendiri dibutuhkan jenis tes berupa praktek secara lisan.

Dalam masalah tersebut, guru terlalu fokus dalam merancang tes tulis yang lebih mengutamakan penguasaan kosa kata, sehingga untuk keterampilan-keterampilan lainnya sering terlupakan. Di samping itu, waktu juga menjadi alasan guru untuk mengkesampingkan adanya tes lisan untuk mengukur kemampuan berbicara siswa karena menurut guru tersebut hal ini sudah terwakilkan ketika proses belajar mengajar berlangsung dikelas.

4. Kemampuan dan psikologi siswa yang bervariatif

Guru juga mengeluhkan kemampuan dan psikologi siswa yang bervariatif dan juga emosi siswa yang sangat sering berubah- ubah. Hal ini dapat mengahambat guru dalam proses belajar mengajar. Contohnya, dengan adanya kemampuan siswa yang tidak seragam maka hal ini menyulitkan guru saat akan memulai materi yang baru karena masih ada beberapa siswa yang belum memahami materi sebelumnya. Dan jika guru mengulang materi yang sebelumnya dengan harapan siswa yang belum memahami dapat mengerti, pada saat proses tersebut siswa yang lebih dahulu memahaminya akan merasa jenuh karena ia telah memahaminya terlebih dahulu. 
Selain itu, emosi siswa sekolah dasar yang cenderung sering berubah-ubah dibutuhkan treatmen khusus dalam menanganinya sehingga banyak tahapan-tahapan pembelajaran yang tidak dapat berjalan sebagai mana mestinya.

5. Lingkungan yang kurang mendukung

Problematika Pembelajaran Kalam dari sudut pandang siswa

a. Siswa masih merasa kesulitan dalam mengucapkan, membaca, dan menulis tulisan Arab.

b. Siswa mudah lupa dengan kosakata-kosakata yang telah dipelajari sebelumnya.

c. Siswa merasa jam pelajaran bahasa Arab lebih lama dari jam pelajaran bahasa Inggris.

Dari beberapa problematika yang ada dilapangan diatas, terdapat salah satu problematika yang menarik penulis untuk membahas lebih lanjut, yaitu problematika dalam melaksanaan evaluasi kemahiran berbicara siswa. Dan setelah dilakukan analisis lebih dalam mengenai hal tersebut maka ditemukan beberapa problematika yang saling berkaitan dalam tahap evaluasi kemahiran berbicara ini. Adapun beberapa problem yang ditemukan diantaranya adalah sebagai berikut:

1) Guru sering mengabaikan evaluasi untuk keterampilan berbicara karena terlalu fokus pada evaluasi tertulis.

Proses evaluasi untuk mengetahui hasil belajar peserta didik yang terjadi di lapangan pada umumnya menggunakan sebuah tes tertulis. Akan tetapi, untuk mengetahui kemampuan siswa dalam berbicara tentu saja dibutuhkan tes yang berbentuk lisan. Menurut hemat penulis masih ada beberapa sekolah yang belum menempatkan tes lisan sama pentingnya dengan tes tulis dalam pembelajaran bahasa Arab. Terdapat beberapa guru yang penulis temui mengaku bahwasannya tahap evaluasi kemahiran berbicara bahasa Arab yang secara khusus disusun untuk dilakukan dengan sengaja dalam bentuk tes lisan masih sering terabaikan. Hal ini dikarenakan dengan terlalu fokusnya guru dalam merancang tes tertulis tanpa memikirkan pentingnya tes lisan.

Disamping itu, banyaknya beban guru saat merancang tes tulis (kisi-kisi, bobot soal, Kriteria Soal, dll) juga dapat menjadi penyebab problem ini. Selain itu, ada juga guru yang menganggap bahwasannya untuk mengetahui keamampuan bahasa siswa cukup hanya dengan melihat hasil tes tulis yang dilakukan siswanya. Hal ini dapat 
diartikan bahwasannya guru tersebut tidak memperhatikan serta tidak mementingkan empat keterampilan bahasa yang terkandung didalam pembelajaran bahasa. Hal tersebut tentu tidak dapat mencapai tujuan pembelajaran yang optimal serta tidak dapat memenuhi empat keterampilan bahasa yang ada.

2) Waktu yang kurang memadai juga membuat guru menomorduakan evaluasi ini.

Waktu yang kurang memadai juga menjadi problematika dalam melaksaakan tes lisan, hal ini juga menjadi faktor penyebab terabaikannya tes lisan dalam proses evaluasi kemahiran berbicara siswa.

Dari beberapa guru yang penulis temui mengaku bahwasannya waktu pelaksanaan evaluasi yang terbatas menjadikan guru untuk menomerduakan tes lisan, dalam hal ini, guru tersebut menyadari bahwasannya tes lisan perlu dilakukan dan sama pentingnya dengan tes tulis. Akan tetapi, karena waktu yang terbatas menjadikan guru mengambil jalan alternatif untuk menomorduakan tes lisan tersebut. Selain itu guru juga beranggapan bahwa tes lisan harus dilakukan satu persatu siswa sehingga hal tersebut membutuhkan waktu yang lebih lama.

Adapun untuk memenuhi nilai yang diminta guru tersebut hanya dapat menyajikan nilai dari keseharian siswa dikelas, tentu saja hal ini tidak optimal untuk melakukan evaluasi serta mengetahui sejauh mana kemampuan siswa dalam berbicara bahasa Arab.

3) Pengajar mengaku kesulitan untuk membuat instrumen yang tepat untuk evaluasi kemahiran berbicara.

Dalam problematika ketiga ini, terdapat guru yang telah menyadari akan pentingnya tes lisan dan telah berusaha untuk melaksanakan tahap tersebut dengan baik. Akan tetapi, banyak dari mereka yang masih belum mengetahui atau merasa kesulitan dalam membuat instrumen yang tepat untuk tes lisan, dan beberapa dari mereka juga kebingungan dengan aspek-aspek yang harus dinalai dalam melaksanakan tes lisan, dan juga beberapa guru tingkat dasar mengaku belum menemukan teknik tes lisan yang sesuai dan tepat untuk digunakan pada siswa tingkat dasar.

4) Kemampuan siswa yang terbatas menghambat berlangsungnya evaluasi kemahiran berbicara. 
Guru juga mengeluhkan kemampuan siswa yang terbatas, psikologi siswa yang bervariatif dan juga emosi siswa yang sangat sering berubah- ubah. Hal ini dapat mengahambat guru dalam membuat instrumen tes lisan.

Problematika diatas merupakan problematika dalam melaksanakan tahap evalusi kemahiran berbicara bahasa Arab pada siswa tingkat dasar yang ditemukan penulis di lapangan. berkenaan dengan problematika tersebut, penulis akan memaparkan beberapa solusi untuk meminimalisisir prolem yang ada serta dapat membantu guru dalam melaksanakan tahap evaluasi kemahira berbicara bahasa Arab ini menjadi lebih baik. Adapun solusinya sebagai berikut:

a. Berkenaan dengan problematika yang diungkapkan pada nomer satu dan dua tentang tahap evaluasi kemahiran berbicara yang sering terabaikan atau dinomerduakan. Penulis berpendapat bahwasannya seorang guru harus meyakini betul tentang pentingnya tahap evaluasi untuk kemahiran ini. Sehingga setelah mengetahui seberapa pentingnya kemahiran ini, guru tersebut akan melakukan beberapa upaya untuk melaksanakan tahap ini dengan baik. Karena dalam hal ini guru peranan yang sangat penting dalam menentukan aspek-aspek apa saja yang harus dinilai, diukur, serta dievaluasi. Dan untuk waktu yang sangat terbatas guru dapat melakukan beberapa teknik tes lisan secara berkelompok dalam skala kecil. Hal ini tentu saja dapat dilakukan oleh guru dengan baik. Dan disamping itu, jika dilaksanakan dalam klompok skala kecil hal ini dapat membantu guru dalam memberikan penilaian karena langsung dihadapkan oleh beberapa siswa yang kemampuannya berbed sehingga dapat dia jadikan perbandingan.

b. Solusi yang penulis tawarkan berkenaan dengan problematika sulitnya membuat instrumen tes lisan salah satunya dalah guru dapat menggunakan instrumen tes yang sama dengan tes tulis. Selain itu, guru juga dapat membuat pertanyaan-pertanyaan berupa percakapan yang sudah diajarkan untuk diujikan kembali. Dalam hal ini banyak sekali referensi yang dapat dijadikan acuan dalam membuat instrumen tes lisan ini. Disamping itu, para guru juga harus lebih banyak membaca dan memiliki banyak referensi agar dapat menguasai tahap-tahap evaluasi yang harus dilakukan dalam melaksanakan tes kemahiran berbicara dengan baik. Hal ini dapat membantu kebutuhan guru untuk mengetahui bentuk, teknik, serta aspek-aspek yang harus dinilai dalam melakukan tes kemahiran berbicara. Disamping itu, penulis juga akan 
sedikit memaparkan teori tentang bentuk tes lisan yang dapat dilakukan oleh guru serta aspek yang harus dinilai dari beberpa buku agar dapat menjadi salah satu referensi pembaca. Menurut Matsna dan Mahyudin (2012:153) secara garis besar tes berbicara dapat berbentuk:

1) Tes pelafalan ${ }_{2}$ adapun yang termasuk dalam tes pelafalan adalah menirukan pelafalan, melafalkan tekanan (nabr) dan intonasi, membaca nyaring teks yang sudah dihafal (mis. Ayat-ayat al-Quran), menyempurnakan kalimat, menjawab pertanyaan sesuai sketsa, dan membaca bersuara.

2) Tes praktek struktur (qawa'id) secara verbal, yang dapat berupa mengubah kata atau kalimat, menghubungkan kalimat, saling bertaya jawab, mengubah kalimat pernyataan menjadi pertanyaan, dan sebagainya.\

3) Tes berbicara menggunakan rangsang visual, yang dapat berbentuk ertanyaan mengenai waktu, jarak, dan ukuran sesuai gambar, membaca angka, mendeskripsikan gambar, menarasikan aktifitas atau gerakan, serta menarasikan cerita bergambar. Rangsang yang berupa gambar ini sangat baik terutama untuk dipergunakan pada anak-anak ataupun pembelajarbahasa Arab tahap awal (mubtadi'in).

4) Tes melalui wawancara dan diskusi, Berbeda dengan teknik diskusi, tes berbicara dengan teknik wawancara ditandai dengan persiapan berupa daftar pertanyaan yang terstruktur yang harus dijawab oleh siswa. Teknik diskusi dan wawancara ini biasanya dilakukan terhadap siswa yang kemampuan bahasa Arabnya sudah dirasa cukup memadai sehingga memungkinkan untuk mengungkapkan pikiran dan perasaanya.

Syihabuddin (2008:198-199) mengungkapkan bahwa aspek-aspek yang dinilai dalam tes keterampilan berbicara meliputi aspek-aspek berikut:

1) Lafal. Aspek ini meliputi (a) tekanan sesuai standar, tidak tampak adanya pengaruh bahasa asing dan bahasa daerah, (b) ucapan yang dipahami, (c) sesekali timbul kesukaran memahami, (d) susah dipahami, (e) sama sekali tidak dapat dipahami.

2) Tata bahasa. Aspek ini meliputi (a) hampir tidak membuat kesalahan, (b) sedikit sekali membuat kesalahan, (c) sering membuat kesalahan, sehingga kadang-kadang mengaburkan pengertian, (d) kesalahan tata bahasa dan susunan kata yang 
menyebabkan pembicaraan sukar dipahami, (e) banyak kesalahannya, sehingga tidak jelas alur pikirannya.

3) Kosakata. Aspek ini meliputi (a) penggunaan kata-kata dan ungkapan yang baik sekali, (b) kadang-kadang digunakan kata dan istilah yang kurang tepat, (c) sering menggunakan kata-kata yang salah dan penggunannya amat terbatas, (d) sering menggunakan kata yang salah yang menyebabkan pembicaraan sukar dipahami, (e) kosakata amat terbatas, sehingga memacetkan pembicaraan.

4) Kefasihan. Aspek ini meliputi (a) pembicaraan lancar sekali, (b) kelancaran sering mengalami gangguan, (c) kecepatan dan kelancaran tampaknya sering diganggu oleh kesulitan bahasa, (d) umumnya pembicaraan tersendat-sendat, (e) pembicaraan sering terhenti dan pendek-pendek

5) Isi Pembicaraan. Aspek ini meliputi (a) alur pembicaraan sangat baik dan runtun, (b) alur topik pembicaraan sedikit tertukar, (c) alur pembicaraan masih bisa dipahami meskipun kurang runtun, (d) alur pembicaraan tidak runtun dan kurang menjelaskan topic, (e) alur pembicaraannya tidak jelas sehingga menyimpang dari topic pembicaraan.

6) Pemahaman. Aspek ini meliputi (a) dapat memahami masalah tanpa kesulitan, (b) dapat memahami percakapan dengan kecepatan normal dan dapat bereaksi secara tepat, (c) dapat memahami sebagian besar percakapan tetapi lambat bereaksi, (d) dapat dikatakan tidak mampu memahami maksud percakapan betapa pun sangat bersahaja.

Dengan adanya kedua teori diatas dapat membantu guru dalam menentukan jenis tes yang akan digunakan serta aspek-aspek yang harus dinilai dan tentunya sesuai dengan tingkat dan kemampuan peserta didik.

a. Berkenaan dengan problematika keempat, maka penulis beranggapan bahwa guru jangan hanya terpaku untuk mengujikan terhadap satu jenis soal saja akan tetapi guru dapat membuat tes yang didalamnya terdapat berbagai macam kriteria soal dari yang mudah, sedang, sukar, dan sangat sukar. Sehingga hal ini dapat membantu guru tersebut memilih soal yang sesuai dengan kemampuan peserta didik yang diujinya.

b. Dari beberapa solusi diatas, penulis akan menambahkan satu teori tentang teknik pelaksanaan tes kemahiran berbicara dimana hal ini dapat membantu dan menginspirasi guru dalam melaksanakan tes kemahiran berbicara siswa. Tes yang ada 
dalam keterampilan berbicara itu banyak macamnya. Berikut ini Syihabuddin (2008: 203-204) membagi jenis teknik tes berdasarkan berbagai sudut pandang yang berbeda:

1) Dilihat dari jenis berbicara yang digunakan terdapat beberapa teknik tes berbicara seperti berikut:1) Teknik bercakap-cakap, 2) Teknik Tanya jawab, 3)Teknik wawancara, 4) Teknik diskusi, 5) Teknik debat, 6) Teknik bermain peran, 7) Teknik berbicara, 8) Teknik berpidato, 9) Teknik berceramah, 10) Teknik lampiran (ekspose).

2) Dilihat dari segi kontak pembicara -pendengar

a) Teknik satu arah (pendengar tidak ikut berbicara)

b) Teknik dua / banyak arah

3) Dilihat dari segi teknik dan penampilan meliputi:
a) Teknik langsung
b) Teknik tak langsung (direkam)

4) Dilihat dari jenis kesiapan pembicara
a) Teknik berbicara spontan
b) Teknik berbicara dengan persiapan
c) Teknik berbicara secara parsial (membacakan dan tidak membacakan)

Ditinjau dari jenis bahasa yang digunakan, terdapat bahasa lisan dan tulisan. Walaupun soal akan dikerjakan secara lisan, sebaiknya soal disiapkan secara tertulis beberapa hari sebelum pelaksanaan. Soal ditulis dalam bentuk tugas atau bentuk persyaratan/ketentuan tertentu (Syihabuddin, 2008:203-204).

\section{SIMPULAN}

Pada kenyataannya, tahap evaluasi untuk kemahiran berbicara siswa di tingkat dasar sering sekali terabaikan dan terlupakan. Terdapat beberapa masalah yang ditemukan terkait pelaksanaan evaluasi kemahiran berbicara siswa di tingkat dasar, diantaranya sebagai berikut: 1) Guru sering mengabaikan evaluasi untuk keterampilan berbicara karena terlalu fokus pada evaluasi tertulis, 2) Waktu yang kurang memadai juga membuat guru menomor duakan evaluasi ini, 3) Pengajar mengaku kesulitan untuk membuat instrumen yang tepat untuk evaluasi kemahiran berbicara, dan 4) Kemampuan siswa yang terbatas menghambat berlangsungnya evaluasi kemahiran berbicara. 
Dari beberapa permasalahan yang ada, terdapat beberapa solusi untuk mengatasinya. Salah satunya adalah guru harus menepatkan evaluasi kemahiran berbicara sama pentingnya dengan beberapa evaluasi kemahiran berbahasa lainnya.

Adapun saran yang dapat penulis berikan kepada para guru bahasa Arab hendaknya para guru dapat memperhatikan seluruh aspek kemahiran bahasa dalam mengajarkannya serta bertanggung jawab untuk mengevaluasinya.

\section{DAFTAR PUSTAKA}

Effendy, A. (2005). Metodologi Pengajaran Bahasa Arab. Malang: Misykat.

Harris, D. P. (1969). Testing English as a Second Language. USA: McGraw-Hill Book Company.

Hermawan, A. (2011). Metodologi Pembelajaran Bahasa Arab. Bandung: PT Remaja Rosdakarya Offset.

Sunendar \& Iskandarwassid. (2008). Strategi Pembelajaran Bahasa. Bandung: Rosdakarya. Mandzur, I. (2011). Lisan Al-Arab. 7th ed. Lebanon: Dar Sader.

Matsna, M \& Mahyudin, E. (2012). Pengembangan Evaluasi dan Tes Bahasa Arab. Tanggerang: Al-Kitabah.

Supriadi. (2013). Evaluasi Pembelajaran Bahasa Indonesia. Gorontalo: UNG Press.

Syihabuddin. (2008). Evaluasi Pengajaran Bahasa Indonesia. Modul: Tidak Diterbitkan. 